Now, and I muse for why, and never find the reason,

I pace the earth, and drink the air, and feel the sun.

Be still, be still, my soul-it is but for a season ;

Let us endure an hour and see in. justice done.

Ay, look! high heaven and earth ail from the prime foundation;

All thoughts to rive the heart are here, and all are vain :

Horror and scorn and hate and fear and indignation-

Oh, why did I awake? when shall I sleep again?

A. E. Housman.

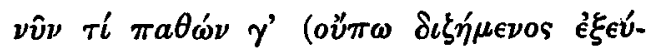
$\rho \eta \kappa a)$

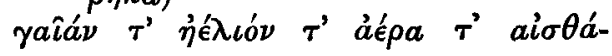

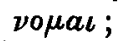

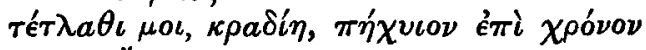
$\ddot{\epsilon} \mu \pi \eta \boldsymbol{s}$

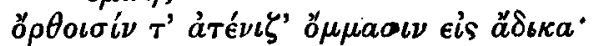

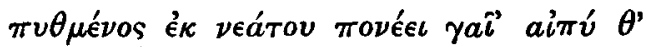
๕̌́os $\theta \epsilon \hat{\omega} \nu$,

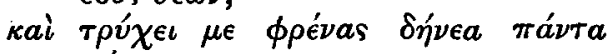
$\mu a ́ \tau \eta \nu$,

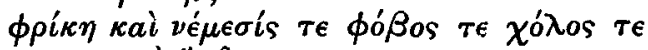
кai है $\chi \theta \rho \eta$.

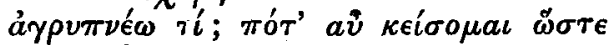
$\lambda i \theta o s$;

HUgo JoHnson.

\title{
CORRESPONDENCE
}

\section{To the Editor of The Classical Review.}

SIR,-I have to thank Mr. Prickard for pointing out my error in attributing the reading 'Tum bibes' (Horace, Od., I. 20. Io.) to Wickham. Let me add that you yourself drew my attention to it, and 1 was under the impression that I had corrected it in the proofs. Such had certainly been my intention. The error was due to a faulty arrangement of the data, and is one that I sincerely regret.

Mr. Prickard's exposition of the figure of speech employed amounts, it seems to me, to a demonstration. The mention of Formian wine (III. 16. 34.), as among the possessions of a favoured class leaves my suggestion with little to rest on; for though it might have been a much worse wine than the others, it was evidently not a poor one.

With regard to the Falernian, though it was undoubtedly a good wine, it does not follow that it was not ranked lower than Caecuban and Falernian. Moreover, its strength, and consequent unsuitability for a convalescent, is to be gathered from such passages as $O d$. I. 27. 10; Od. II. I1. 9. ; Sat. I. 10. 24. ; Epp. I. 14. 34 ; Sat. II. 2. 16.

The fact that the ode is not an invitation scarcely invalidates, I think, my conjecture. In any case Maecenas was being prepared for a humble reception.

On the whole, however, I must regard the interrogative form as inadvisable. If my conjecture were correct the Formian wine must have been quite a poor one, and could hardly have been placed by Horace among envied possessions. On Mr. Prickard's interpretation the ode seems to me to have point enough.

Sydney Teachers' College, L. H. ALLEN.
To the Editor of THE ClASSICAL Review.

SIR, - I shall be obliged if you can find room for the following suggestion:

In Catullus XXIX. for the pointless malum of 1. 21 read Lamum:

Quid hunc Lamum fovetis? aut quid hic potest Nisi uncta devorare patrimonia?

Formiae, the 'Mamurrarum urbs' of Horace (S. i. 5. 37), is called by Ovid (Metam. XIV. 233) 'Urbs Lami,' from its founder Lamus (Odys. X. 8r. Hor., C. iii. 17). Catullus suggests a comparison between two degenerates, a ' $\mathrm{Ro}$ mulus' turned 'cinaedus' and a 'Lamus' become 'decoctor.' Note that this correction seems to tell, and to tell decisively, in favour of something like Lachmann's ${ }^{1}$-restoration of that locus conclamatus, 1.23 ,

Eone nomine, urbis o piissime

Socer generque, perdidistis omnia?

For in Homer (loc. cit.) Lamus' people are cannibals and, with this 'learned' allusion added, the irony of 'piissime' becomes more pointed than ever' : "Pietas incarnate ruining everything for the sake of - a cannibal!' The form 'piissimus' is of course doubtful ; and so the scribe of $V$ or $V$ 's exemplar found it. That

1 Haupt preferred 'orbis o piissimei. Recently M. Saenger in a Russian periodical, while himself proposing 'inclutissimei,' cites from $T h$. Korsch 'urbis o piissimei.' Some such modification of Lachmann's conjecture may seem desirable.

2 'The words 'Mamurram,' 'vorax' (bis), 'comesset,' 'elluatus' all prepare us for the hit in Lamum :-_devorare' drives the point home. Cf. also Ovid's 'Laestrygonis impia tinxit ora cruore suo' (Metam. XIV. 237). On these 'Neptuni filii' see Aul. Gellius, xv. 21. 